\title{
Common Loon Reproductive Success in Canada: the West is Best but Not for Long
}

\section{Succès reproducteur du Plongeon huard au Canada : l'Ouest est mieux, mais pas pour longtemps}

\author{
Douglas C. Tozer ${ }^{1}$, C. Myles Falconer ${ }^{l}$ and Debbie S. Badzinski ${ }^{l}$
}

\begin{abstract}
Reproductive success of Common Loons (Gavia immer) is a powerful indicator of aquatic ecosystem health, especially in relation to mercury and acid precipitation. We examined relationships between Common Loon reproductive success and longitude, year, lake area, and $\mathrm{pH}$ across southern Canada using data collected from 1992 to 2010 by participants in Bird Studies Canada's Canadian Lakes Loon Survey. Our goal was to indirectly describe the health of lakes in southern Canada with respect to mercury and acid precipitation. The overall model-predicted number of six-week-old young per pair per year was 0.59 (95\% confidence limits: $0.56-0.62)$. Six-week-old young per pair per year decreased by 0.19 from west-to-east $\left(-127^{\circ}\right.$ to $-52^{\circ}$ longitude), decreased by 0.14 between 1992 and 2010, increased by 0.22 as lake area increased from 10 to 3000 ha, and increased by 0.43 as acidity decreased from $\mathrm{pH} 5$ to 9 . The relationships were likely linked to acid- and temperature-mediated exposure to methylmercury and/or acid-induced reductions in forage fish. The temporal decrease was unexpectedly steeper in southwestern than in southeastern Canada. Projections suggested that reproductive success across southern Canada may not drop below the demographic source-sink threshold until 2016 (range: 2009-2029). Reproductive success on pH 6.0 lakes, however, may have passed below the source-sink threshold as early as 2001 (1995-2009), whereas reproductive success on pH 8.0 lakes may not pass below the threshold until $\sim 2034$ (2019-2062). There were $\sim 0.1$ more six-week-old young per pair per year on 2500 ha lakes than on 20 ha lakes. Reproductive success crossed below the source-sink threshold on 20 ha lakes at pH 6.4 (5.8-7.1) and on 2500 ha lakes at pH 5.5 (4.1-6.6). Our results show that citizen science is powerful for monitoring ecosystem health and indirectly support further action to abate emissions of mercury and the harmful components of acid precipitation throughout North America and globally.
\end{abstract}

RÉSUMÉ. Le succès reproducteur du Plongeon huard (Gavia immer) est un indicateur puissant de la santé des écosystèmes aquatiques, particulièrement sur le plan du mercure et des précipitations acides. Nous avons examiné les relations entre le succès reproducteur du plongeon et la longitude, l'année, la superficie du lac et son $\mathrm{pH}$, dans l'ensemble du sud du Canada à l'aide des données récoltées de 1992 à 2010 par les participants de l'Inventaire canadien des Plongeons huards chapeauté par Études d'oiseaux Canada. Cette étude visait la description indirecte de la santé des lacs du sud du Canada, plus particulièrement en ce qui a trait au mercure et aux précipitations acides. Le nombre global de jeunes de six semaines par couple et par an prédit par le modèle s'élevait à 0,59 (limites de confiance à $95 \%: 0,56-0,62$ ). Le nombre de jeunes de six semaines par couple et par an a diminué de 0,19 de l'ouest vers l'est (du 127e au 52e degré de longitude ouest), a diminué de 0,14 de 1992 à 2010, a augmenté de 0,22 avec l'augmentation de la superficie du lac de 10 à 3000 ha, et enfin, a augmenté de 0,43 avec la baisse de l'acidité, d'un $\mathrm{pH}$ de 5 à 9 . Les relations étaient vraisemblablement liées à l'exposition au méthylmercure induite par la température et l'acidité, et/ou à la réduction des poissons-fourrage induite par l'acidité. La baisse observée sur le plan temporel était plus prononcée dans le sud-ouest que dans le sud-est du Canada - un résultat imprévu. Les projections indiquent que le succès reproducteur dans l'ensemble du sud du Canada pourrait ne pas descendre sous le seuil démographique source-puits avant 2016 (étendue : 2009-2029). Toutefois, le succès reproducteur sur les lacs de $\mathrm{pH} 6,0$ pourrait être passé sous le seuil source-puits dès 2001 (1995-2009), tandis que le succès sur les lacs de pH 8,0 pourrait ne pas descendre sous ce seuil avant 2034 (2019-2062). Il y avait $\sim 0,1$ jeune de six semaines par couple et par an de plus sur les lacs de 2500 ha comparativement aux lacs de 20 ha. Le succès reproducteur était inférieur au seuil source-puits sur les lacs de 20 ha et de pH 6,4 $(5,8-7,1)$ et sur les lacs de 2500 ha et

${ }^{1}$ Bird Studies Canada

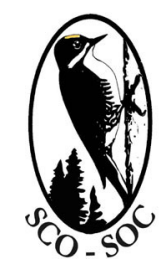

Sponsored by the Society of Canadian Ornithologists and Bird Studies Canada Parrainée par la Société des ornithologistes du Canada et Études d'oiseaux Canada

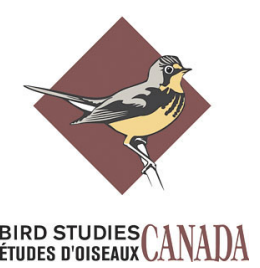


de pH 5,5 (4,1-6,6). Nos résultats montrent que la science citoyenne est importante pour suivre la santé des écosystèmes et soutenir indirectement les actions futures destinées à réduire les émissions de mercure et des composants nocifs des précipitations acides à travers l'Amérique du Nord et l'ensemble de la planète.

Key Words: acid rain; citizen science; Common Loon; ecosystem health; Gavia immer; mercury; monitoring; pollution

\section{INTRODUCTION}

The Common Loon (Gavia immer) is a conspicuous migratory fish-eating bird, which breeds on lakes throughout most of mainland Canada and parts of the U.S., but over-winters predominantly on the open ocean (McIntyre 1994). Adults are long-lived (> 20 years in the wild), typically return to the same breeding territory year after year, and provision their young almost exclusively with fish from the natal lake (Evers et al. 2010). These characteristics, and its high position within the aquatic food chain, make the Common Loon a powerful indicator of local aquatic ecosystem health, especially in relation to mercury and acid precipitation (Strong 1990, Evers 2006).

In the past few decades there has been a flurry of research establishing links between mercury, acid precipitation, and Common Loon reproductive success (e.g., Alvo 2009, Evers et al. 2008). As well, numerous broad-scale long-term citizen science programs have collected data on Common Loon reproductive success as an indicator of mercury and acid precipitation, e.g., across southern Canada, Alaska, Maine, Michigan, Minnesota, Montana, New Hampshire, Vermont, Washington, and Wisconsin (Evers 2007). Although these programs have not typically paired measures of Common Loon reproductive success with direct measures of mercury and acid precipitation, the body of evidence that links the effects of these pollutants with impaired reproductive success is now so strong and well understood that indirect inferences are justified.

Mercury is a potent toxin, which causes various neurological and physiological problems in vertebrates (Scheuhammer et al. 2007, Seewagen 2010). Common Loons with elevated concentrations of mercury in their tissues are more lethargic and engage in fewer high-energy activities like collecting food for young and defending breeding territories compared to adults with lower mercury concentrations (Evers et al. 2008). Young with elevated blood mercury concentrations seek energy-saving rides on the backs of adults less often, probably spend more energy preening, and as a result may be less likely to fledge than young with lower blood mercury concentrations (Nocera and Taylor 1998). Captive-reared young dosed with elevated, but ecologically relevant, mercury burdens in carefully controlled laboratory experiments suffer from compromised immune systems and are less able to avoid predators compared to young dosed with lower mercury burdens (Kenow et al. 2007, 2010). Maximum observed Common Loon reproductive success drops to $50 \%$ on lakes where mercury concentrations are $\sim 0.2 \mathrm{ug} / \mathrm{g}$ (wet weight) in fish and $\sim 4 \mathrm{ug} / \mathrm{g}$ (wet weight) in blood of female loons and to $0 \%$ when mercury concentrations exceed approximately double these values (Barr 1986, Burgess and Meyer 2008). Thus, mercury clearly impairs Common Loon reproductive success.

The same is true for acid precipitation. Acids, and the toxic metals they mobilize, interfere with fish gill function, which in turn reduces fish growth, reproduction, and survivorship, and results in lower fish abundance in more acidic lakes (Howells et al. 1983). This is problematic for Common Loons because fish comprise a large portion of the diet of breeding adults and young (Alvo 2009, Evers 2007). Adults on extremely low pH lakes, i.e., highly acidic lakes, spend 2 - 4 times longer capturing prey for young than adults on high $\mathrm{pH}$ lakes because potential prey items are 30 - 40 times less abundant (Parker 1988). As a result, territorial breeding adults often fail to produce young on extremely low $\mathrm{pH}$ lakes, but as $\mathrm{pH}$ increases, formerly unsuccessful territorial pairs subsequently fledge young (Alvo 2009). In a minority of lakes, low $\mathrm{pH}$ results in conditions that benefit breeding Common Loons (e.g., Brown 1982, Eriksson 1985, Burgess and Meyer 2008). Nevertheless, Common Loons generally fail to produce young on lakes with $\mathrm{pH}<4.3$, produce young but incur losses due to brood reduction at $\mathrm{pH} 4.4$ to 6.0 , and produce consistently higher numbers of young at $\mathrm{pH}>6.0$ (Alvo 2009, Alvo et al. 1988). Thus, acid precipitation, like mercury, directly impairs Common Loon reproductive success.

Mercury, however, interacts with acid precipitation and water temperatures in ways that further impair Common Loon reproductive success. Most mercury makes its way up the food chain to loons in the form of methylmercury (Grigal 2002, 2003). The concentration of methylmercury in animal tissues increases or biomagnifies each time one animal eats another along the chain (Driscoll et al. 2007). The amount of methylmercury in lake water available to enter food chains is governed by multiple biotic and abiotic methylation and demethylation pathways; thus, uptake is greatest where the methylation rate exceeds the demethylation rate (Celo et al. 2006). Sulfur oxides from acid precipitation favor methylation because they increase the activity of sulfur-reducing bacteria, which convert large amounts of mercury to methylmercury (Jeremiason et al. 2006). Higher water temperatures also increase the activity of the bacteria and favor methylation over demethylation (Shin and Krenkel 1976, Wright and Hamilton 1982, Ramlal et al. 1993). Plus, acid precipitation results in greater bioavailability of mercury because acids mobilize bound mercury and methylmercury (Xun et al. 1987, Winfrey 
and Rudd 1990). Thus, methylmercury is more abundant and loons are at greater risk of mercury toxicity where lake water $\mathrm{pH}$ is lower and temperature is higher.

There are now extensive data that describe the geographic and temporal patterns of mercury and acid precipitation, which combined with the pathways described above, allow predictions of where and when mercury and acid precipitation may negatively affect Common Loon reproductive success. Mercury and the harmful components of acid precipitation are released to the atmosphere during the combustion of fossil fuels, the largest source being coal-fired power plants (Driscoll et al. 2001, Pirrone et al. 2010). Southern Canada receives airborne mercury from all over the globe, primarily because mercury can persist in the atmosphere for up to a year or more before returning to the surface, which gives it ample time to be carried long distances by prevailing winds (Schroeder and Munthe 1998). As a result, measurements of gaseous mercury from 11 permanent monitoring stations across southern Canada suggest that deposition is only slightly higher in the west than the east (Kellerhalls et al. 2003, Temme et al. 2007). By contrast, the harmful components of acid precipitation are produced predominantly midcontinent and carried eastward and northeastward by prevailing winds (Schindler 1988). Sulfur oxide deposition in southeastern Canada (Ontario, Quebec, Maritime Provinces) is 2 - 3 times that in southwestern Canada (British Columbia, Prairie Provinces; Aherne et al. 2010). Lake water decreases from $\mathrm{pH} 7.7$ in western Canada (longitude $127^{\circ}$ ) to $\mathrm{pH} 6.2$ in eastern Canada (longitude $52^{\circ}$ ) based on linear regression of data summarized in Minns et al. (2008). Thus, lakes in eastern Canada typically have lower $\mathrm{pH}$ than lakes in western Canada, which likely explains why methylmercury increases in Canada from west-to-east in lake water (Eckley and Hintelmann 2006), fish (Kamman et al. 2005, Jewett and Duffy 2007), and loons (Evers et al. 1998), and, at least in part, why Common Loon reproductive success decreases from west-to-east in southern Canada (Timmermans and Jones 2002).

Smaller lakes tend to be shallower and therefore warmer than larger lakes (Bodaly et al. 1993). By virtue of their volume, smaller lakes also have lower total numbers of fish than larger lakes (Alvo et al. 1988, Piper et al. 2012). Moreover, some smaller lakes receive relatively larger inputs from acid precipitation and hold fewer substances that neutralize acids compared to larger lakes (Eilers et al. 1983), which means that smaller lakes generally have lower $\mathrm{pH}$ than larger lakes (e.g., Rago and Wiener 1986, Matuszek and Beggs 1988, McNicol et al. 1995). Thus, smaller lakes typically are warmer and have lower $\mathrm{pH}$ than larger lakes, which likely explains why methylmercury is more abundant in smaller lakes (Bodaly et al. 1993, Jeremiason et al. 2006). All of these factors in turn likely explain why Common Loon reproductive success and survival of young declines with decreasing lake area (Alvo 2009, McNicol et al. 1995, Piper et al. 2012).
Emissions of mercury and the harmful components of acid precipitation increased during most of the 20th century and are now declining, yet inputs to aquatic systems remain well above both historical inputs and inputs deemed safe for aquatic wildlife (Lockhart et al. 1998, Morrison 2004, Perry et al. 2005). Over the past 20 years, the fish in as many as $30 \%$ of breeding lakes in Ontario (Scheuhammer and Blancher 1994), $26 \%$ of breeding Common Loons in southern Quebec (Champoux et al. 2006), and $92 \%$ of breeding Common Loons in the Kejimkujik region of Nova Scotia (Burgess et al. 2005) have contained enough mercury to lower maximum reproductive success to $50 \%$. As of the mid-1990s, acid deposition exceeded critical levels for healthy wildlife in as much as $75 \%$ of eastern Canada (Morrison 2004). In addition, methylmercury concentrations are increasing in some locations because of multiple interacting factors that cause methylmercury to increase even though mercury deposition and acid precipitation have declined (Watras and Morrison 2008). For example, methylmercury increased in fish between the mid-1990s and mid-2000s in Wisconsin, Minnesota, and Nova Scotia (Madsen and Stern 2007, Monson 2009, Rasmussen et al. 2007, Wyn et al. 2010) and mercury increased in Common Loons from 2002 to 2010 in Wisconsin (Meyer et al. 2011). Similarly, $\mathrm{pH}$ increased in relatively few lakes in eastern Canada during the 1990s, despite concurrent reductions in acid emissions, partly because the acid neutralizing capacity of most lakes remained insufficient to buffer acid inputs (Doka et al. 2003, Jefferies et al. 2003a,b). Thus, mercury and acid precipitation continue to threaten Common Loon reproductive success and associated lake health in Canada, which likely explains why reproductive success of Common Loons in Ontario declined between 1981 and 1999 (Jeffries et al. 2003a, Weeber 1999).

We determined relationships between Common Loon reproductive success and longitude, year, lake area, and $\mathrm{pH}$ across southern Canada using data collected between 1992 and 2010 by participants in Bird Studies Canada's Canadian Lakes Loon Survey (CLLS). Our ultimate goal was to indirectly describe patterns in the health of southern Canadian lakes with respect to mercury and acid precipitation, which we justified based on the well-established geographic and temporal patterns of the pollutants and the body of evidence that links the pollutants with Common Loon reproductive success. Thus, we predicted that the number of six-week-old young per pair per year would (1) decrease with increasing longitude, i.e., decrease from west-to-east, (2) decrease over time, (3) increase with increasing lake area, and (4) increase with increasing pH (e.g., McNicol et al. 1995, Weeber 1999, Timmermans and Jones 2002). We further predicted that longitude $\times$ year, year $\times \mathrm{pH}$, and lake area $\times \mathrm{pH}$ interactions would be important (e.g., Alvo 2009, Evers et al. 1998, Meyer et al. 2011, Piper et al. 2012, Weeber 1999). We placed our results in a demographic context by estimating whether reproductive success is sufficient to offset adult and juvenile 
mortality, i.e., a demographic source, which is identified as a conservation priority for the Common Loon (Evers 2007).

\section{METHODS}

\section{Study design}

The CLLS began in Ontario in 1981 and expanded throughout southern Canada in the early 1990s. We included data only from 1992 onward because at that point there was reasonably good geographic coverage of lakes in southern Canada $(\sim 300$ lakes per year on average). Participants in the CLLS selected survey lakes, and surveyed either the entire lake or a portion of it each year. Participants made observations on a minimum of 3 days and up to 140 days at each lake per breeding season $(35.3 \pm 29.9$ [mean \pm SD] days per breeding season). At least one day was spent in June to determine number of territorial pairs, in July to determine number of hatchlings per pair, and in mid-to-late August to determine number of six-week-old young per pair. Pairs were defined as territorial adults with young, or a nest, or a mate. Loons were considered territorial if they were regularly associated with a particular portion of the lake or displayed territorial behavior, such as male yodel calls. Participants determined the age of the young by comparing the relative size of young to nearby adults; sixweek-old young were $>\sim 70 \%$ adult size. The CLLS protocol is described in more detail elsewhere (McNicol et al. 1995, Badzinski and Timmermans 2006, Bird Studies Canada 2011).

\section{Statistical analyses}

We considered explanatory variables from the CLLS dataset that generated broad-scale predictions of reproductive success based on the multitude of previous knowledge of exposure of breeding Common Loons to methylmercury and acid precipitation: longitude, year, lake area, and $\mathrm{pH}$. Longitude was in decimal degrees, e.g., $-78.0^{\circ}$; year was recoded as $1992=1,1993=2 \ldots 2010=19$; lake area was $\log _{10^{-}}$ transformed in hectares (hereafter "log lake area"); and $\mathrm{pH}$ was typically a single measurement per lake from any year that it was available, otherwise values were averaged or combined via the procedure described in Minns et al. (2008). All explanatory variables were treated as continuous. The response variable was the number of six-week-old young per pair per year $(0,1$, or 2$)$. Common Loons of this age have attained nearly adult size, and with it, a much lower chance of being depredated, making them a reasonable indicator of the number of young actually fledged (Evers 2007).

We used generalized linear mixed models with log-link functions, assuming Poisson distributions, which were suitable for the count structure of our data (Zuur et al. 2009) and an information theoretic approach via Akaike's information criterion to select a best approximating model or set of models (Burnham and Anderson 2002). We initially tested whether our explanatory variables as a group satisfactorily predicted the response variable via a likelihoodratio test between the intercept-only and global model
(Tabachnick and Fidell 1996). We did this because even though AIC model selection identifies the best model or models among those considered, it is possible that only the best of several bad models are selected (Burnham and Anderson 2002). We assessed the accuracy of the best model, i.e., model fit, by calculating mean and median absolute error of predicted versus observed values for the data that were used to build the model, i.e., 1992 to 2010 , training set, and for data that were withheld from model building, i.e., 2011, validation set (Willmott and Matsuura 2005).

Our analyses were completed in two parts. First, we considered all one- and two-variable combinations of longitude, year, and log lake area; longitude $\times$ year interaction; and an interceptonly and global model, which included all of the explanatory variables and the interaction, a total of nine candidate models. For this model set we used all breeding attempts where we had longitude, year, and lake area information. We were unable to assess $\mathrm{pH}$ in this part of the analysis because our $\mathrm{pH}$ data in western Canada were too sparse. Thus, including $\mathrm{pH}$ in this model set would have biased the estimates because reproductive success is known to be higher in the west than in the east (Timmermans and Jones 2002). Instead, we considered the effect of $\mathrm{pH}$ with a reduced dataset in a second analysis in which we considered all one-, two-, and threevariable combinations of longitude, year, log lake area, and $\mathrm{pH}$; longitude $\times$ year, year $\times \mathrm{pH}$, and log lake area $\times \mathrm{pH}$ interactions; and an intercept-only and global model, which included all of the explanatory variables and all of the interactions, a total of 25 candidate models. For this second model set we used all breeding attempts where we had longitude, year, lake area, and $\mathrm{pH}$ information, resulting in a different, but largely overlapping, dataset than the one used to fit the model set described in part one of the analysis. We suspected that the dataset used in the first part of the analysis was best for assessing the importance of longitude, year, and log lake area, whereas the dataset used in the second part of the analysis was best for assessing the importance of $\mathrm{pH}$.

There was little correlation among the explanatory variables in part one or part two of the analysis $(-0.21<r<0.29)$, suggesting that multicollinearity was not an issue (Tabachnick and Fidell 1996). We included a random intercept for each lake in all models because $\sim 50 \%$ of the lakes surveyed each year, on average, had reproductive success data for $>1$ pair of loons $(2.8 \pm 2.1$ pairs/lake/year [mean $\pm \mathrm{SD}$ ]; range: $2-43$ pairs/lake/year). We also duplicated all analyses using data from one randomly chosen loon pair per lake per year, but got similar parameter estimates and errors, so we report the fuller analysis with all of the data and a random intercept for each lake.

We considered models with QAIC $_{c}$ values within seven of the best model (lowest $\mathrm{QAIC}_{\mathrm{c}}$ value) to have support, i.e., models with $\triangle \mathrm{AIC}<7.0$ were considered important (Burnham et al. 2011). Supported models, which differed from the best model 
only by an additional single variable, were considered for further inference only if maximized log likelihoods were less than the maximized $\log$ likelihood of the best model and effects appeared to be biologically meaningful (Arnold 2010). This is an important distinction because supported models that differ from the best model only by an additional single variable and that have essentially the same maximized log likelihood, may be biologically uninformative and should be ignored (Burnham and Anderson 2002). We used QAIC $_{c}$ because variance inflation measures, i.e., deviance/residual degrees of freedom, were 1.2 (Burnham and Anderson 2002). We used model-averaged parameter estimates and unconditional standard errors to avoid model-selection uncertainty (Burnham and Anderson 2002).

To assess support for our predictions we examined modelaveraged parameter estimates and associated confidence limits for each explanatory variable included in the supported set of models; variables with $95 \%$ confidence limits that did not overlap zero were considered important. To aid with the interpretation, we plotted reproductive success as a function of each important explanatory variable using the best model that included the variable, with all other variables in the model held at median values. We also included means of the response variable across each of several arbitrary bin classes and 95\% confidence limits on figures to illustrate model fit. We assigned bin classes so that we had a reasonable sample size in each bin. We plotted means instead of our large sample of raw data to avoid cluttered figures that were difficult to interpret; therefore, it should be noted that these means were not the data used to fit the models plotted on the same figure.

We also considered two-way interactions, which appeared in supported models. We visually explored two-way interactions by plotting one of the explanatory variables as a function of reproductive success at multiple values of the second explanatory variable, which is a standard approach for interpreting interactions between two continuous explanatory variables (e.g., Flom and Strauss 2003). As above, we included means on these figures across several meaningful arbitrary bin classes to illustrate model fit.

We illustrated demographic source-sink status on some figures by including a horizontal line representing the reproductive rate required to maintain stable numbers of breeders based on long-term data from locations throughout the southeastern portion of the species' breeding range, i.e., 0.48 six-week-old young per pair per year (Evers 2007), which we assumed was representative of the value throughout southern Canada. We estimated the values of explanatory variables where the modelpredicted number of six-week-old young per pair per year, and its lower and upper 95\% confidence limit (reported as a range), dropped below the demographic source-sink threshold, i.e., when it crossed below the horizontal line on figures, by solving regression equations with reproductive success set equal to 0.48 six-week-old young per pair per year (Evers 2007).

The areas of lakes were estimated from maps or obtained from various other sources. Estimates of $\mathrm{pH}$ were obtained from the datasets summarized by Minns et al. (2008) or similar sources. Because of sparseness of data, we omitted lakes $>3000$ ha in area from analyses. We also omitted lakes that appeared to us to be spatial outliers, leaving the lakes shown in Figure 1 for analysis. We considered data only for Common Loon breeding pairs where the participant reported the number of six-weekold young in mid-to-late August, regardless of the number of days the participant spent surveying. All analyses were conducted using the $\mathrm{R}$ programming language ( $\mathrm{R}$ Development Core Team 2011); models were fitted using package lme4 (Bates et al. 2012) and $\mathrm{QAIC}_{\mathrm{c}}$ tables were generated using package AICcmodavg (Mazerolle 2013).

Fig. 1. Lakes with data collected by participants in Bird Studies Canada's Canadian Lakes Loon Survey used to determine patterns in Common Loon (Gavia immer) reproductive success across southern Canada between 1992 and 2010.

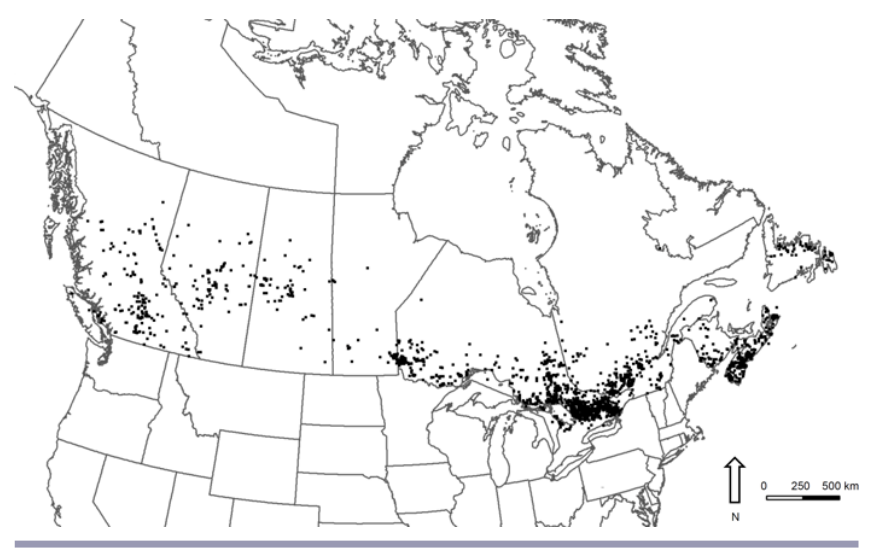

\section{RESULTS}

The dataset contained reproductive output for 9151 breeding attempts by pairs on 1213 lakes between 1992 and 2010. The number of breeding pairs surveyed per year $(482 \pm 166$ [mean \pm SD]) ranged from 240 to 861 (Fig. 2). Correspondingly, the number of lakes surveyed per year $(280 \pm 123)$ ranged from 119 to 579 and declined between 1992 and 2010 (linear regression: $F_{1,17}=25.0, P=0.0001$; Fig. 2). However, there was no relationship between the number of lakes surveyed per year and the number of six-week-old young produced per pair per year (linear regression: $F_{1,17}=0.22, P=0.6480$ ), which suggested that the number of lakes surveyed per year was not a confounding variable. Most lakes (80\%) were surveyed in 7 or fewer of the 19 years, and many lakes (49\%) were surveyed in only 1 or 2 of the 19 years (Fig. 2). 
In the first part of the analysis, we considered the effects of longitude, year, lake area, and a longitude $\times$ year interaction on reproductive success for all 9151 breeding attempts. We were unable to assess $\mathrm{pH}$ in this part of the analysis because our $\mathrm{pH}$ data in western Canada were too sparse; $5 \%$ of breeding attempts occurred west of Ontario, i.e., west of $-100^{\circ}$ longitude, if $\mathrm{pH}$ was included, whereas $16 \%$ occurred west of Ontario if $\mathrm{pH}$ was not included. Instead, we considered the effect of $\mathrm{pH}$ with a reduced dataset in the second part of the analysis described below.

Fig. 2. Number of lakes or pairs of Common Loons (Gavia immer) surveyed per year (upper panel) and the number of lakes as a function of the number of years surveyed (lower panel) by participants in Bird Studies Canada's Canadian Lakes Loon Survey between 1992 and 2010. Numbers above bars show the value of each bar as a percent of the total number of lakes surveyed.

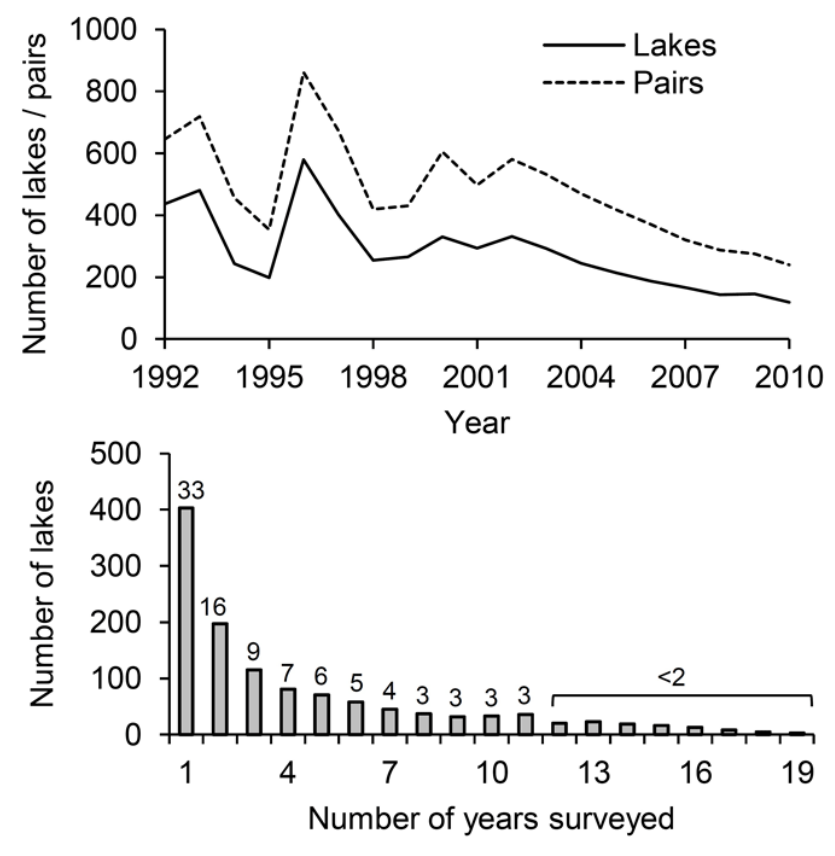

The global model provided significantly better fit to the data than the constant-only model $\left(\chi^{2}=60, \mathrm{df}=4, P<0.0001\right)$. The global model was also the best model explaining variation in reproductive success (Akaike weight $[w]=0.95$; Table 1). A second model containing only year and log lake area also received support $(\triangle \mathrm{AIC}=6.0$ and $w=0.05$; Table 1$)$. Confidence limits around model-averaged parameter estimates for longitude, year, and log lake area did not include zero (Table 2). There was little support for any of the other models $(\triangle \mathrm{AIC}>18.5$ and $w<0.00$; Table 1$)$. The best model predicted reproductive success with a mean and median absolute error of 0.6 and 0.5 six-week-old young per pair per year, respectively, and predicted reproductive success in 2011 with a mean and median absolute error of 0.7 and 0.5 sixweek-old young per pair per year, respectively.

Table 1. Model selection results for nine candidate models explaining patterns in Common Loon (Gavia immer) reproductive success as a function of longitude, year, and lake area across southern Canada between 1992 and 2010. K = number of parameters; QAICc $=$ quasiliklihood Akaike's information criterion; $\mathrm{w}=$ Akaike weight. Parameter estimates with 95\% confidence limits (lower, upper) are shown below for the best model; model-averaged estimates are given in Table 2.

\begin{tabular}{|c|c|c|c|c|}
\hline Model & $K$ & $Q A I C c$ & $\Delta \mathrm{QAICc}$ & $w$ \\
\hline $\begin{array}{l}\text { Longitude }+ \text { Year }+ \text { Log Lake Area }+ \\
\text { Longitude }^{*} \text { Year }^{\dagger}\end{array}$ & 6 & 7854.6 & 0.0 & 0.95 \\
\hline Year + Log Lake Area & 4 & 7860.6 & 6.0 & 0.05 \\
\hline Longitude + Year + Longitude $*$ Year & 5 & 7873.1 & 18.5 & 0.00 \\
\hline Longitude + Year & 4 & 7873.4 & 18.8 & 0.00 \\
\hline Longitude + Log Lake Area & 4 & 7877.5 & 22.9 & 0.00 \\
\hline Year & 3 & 7877.7 & 23.1 & 0.00 \\
\hline Log Lake Area & 3 & 7881.8 & 27.2 & 0.00 \\
\hline Longitude & 3 & 7895.5 & 40.9 & 0.00 \\
\hline Intercept-only & 2 & 7898.2 & 43.6 & 0.00 \\
\hline
\end{tabular}

The overall model-predicted number of six-week-old young per pair per year was 0.59 (95\% confidence limits: $0.56-0.62$ ). The number of six-week-old young per pair per year decreased by 0.19 from west-to-east (longitude: $-127^{\circ}$ to $-52^{\circ}$ ) and by 0.14 between 1992 and 2010 (Fig. 3). However, the longitude $\times$ year interaction suggested that the temporal decrease was steeper in southwestern $\left(-120^{\circ}\right.$ longitude) than in southeastern $\left(-60^{\circ}\right.$ longitude) Canada (Fig. 4). By contrast, the number of six-week-old young per pair per year increased by 0.22 as lake area increased from 10 to 3000 ha (Fig. 3). Projections from the best model suggested that reproductive success across southern Canada may not drop below the source-sink threshold of 0.48 young per pair per year (Evers 2007) until 2016 (range: 2009-2029). Projections also suggested that reproductive success may not cross below the source-sink threshold until 2016 (2007-2029) in the west and 2015 (2003-2126) in the east, despite differences in the steepness of the decline over time (Fig. 4).

In the second part of the analysis, we considered the effect of $\mathrm{pH}$, along with the effects of longitude, year, lake area, and longitude $\times$ year, year $\times \mathrm{pH}$, and log lake area $\times \mathrm{pH}$ interactions on reproductive success for 7597 breeding attempts where all four of these pieces of information were known. The global model provided significantly better fit to the data the constant-only model $\left(\chi^{2}=32, \mathrm{df}=7, P<0.0001\right)$. The best model explaining variation in reproductive success contained only year, $\log$ lake area, and $\mathrm{pH}(w=0.30$; Table 3$)$. There 
Table 2. Descriptive statistics, interquartile range (IQR), and model-averaged parameter estimates (Estimate) and associated 95\% confidence limits (95\% CLs) for explanatory variables used to model patterns in Common Loon (Gavia immer) reproductive success across southern Canada between 1992 and 2010. Model-averaged parameter estimates and associated 95\% CLs for longitude, year, log lake area, and intercept are based on the models in part one of the analysis (Table 1); for $\mathrm{pH}$ they are based on models in part two of the analysis (Table 3).

\begin{tabular}{lccccc}
\hline \hline Variable & Median & Min & Max & IQR & Estimate \\
\hline Longitude & -78.7 & -127.6 & -52.8 & 7.5 & -0.0044 \\
Year $^{\dagger}$ & 2000 & 1992 & 2010 & 8 & -0.014 \\
Lake Area $^{\dagger}$ & 256 & 3.8 & 2908 & 840 & 0.16 \\
$\mathrm{pH}$ & 7.1 & 4.2 & 10.9 & 1.4 & 0.19 \\
Intercept & -- & -- & -- & $--0076,-0.0012$ & $0.021,-0.0093$ \\
\hline
\end{tabular}

Year was re-coded as 1992=1, 1993=2, .., 2010=19 for all analyses; uncoded values are given here for ease of interpretation.

${ }^{\ddagger}$ Lake area was $\log _{10}$-transformed for all analyses; back-transformed values are given here in ha for ease of interpretation.

Fig. 3. Reproductive success of Common Loons (Gavia immer) across southern Canada as a function of longitude, year, lake area, or pH between 1992 and 2010. Shown are model-averaged predictions from the best model that included the variable (solid lines, model; dashed lines, 95\% confidence limits), with all other variables in the model held at median values. Longitude, year, and log lake area are based on models in part one of the analysis (Table 1), whereas $\mathrm{pH}$ is based on models in part two of the analysis (Table 3). Means are shown across each of several arbitrary bin classes (dots) to illustrate model fit, but be aware that these means were not the data used to fit the model. Note that lake area is shown on a log scale.
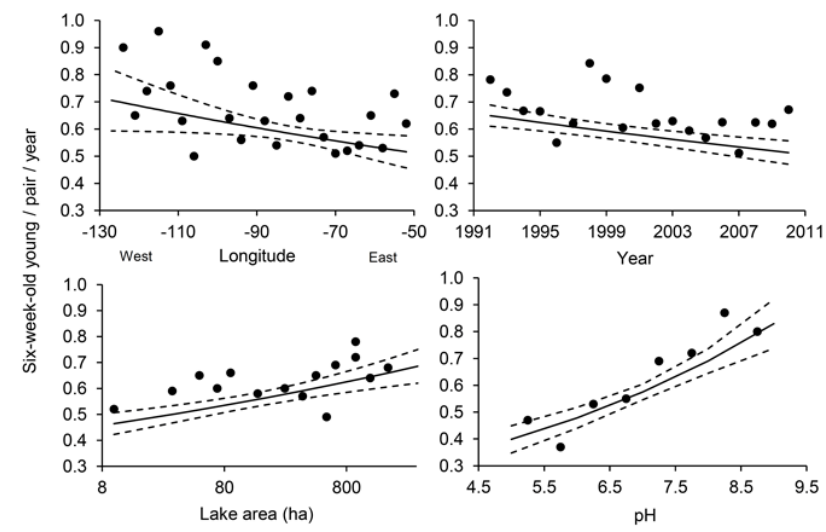

was also support for seven other models $(\triangle \mathrm{AIC}<4.2$ and $w$ $>0.04$; Table 3 ). The second and third best models differed from the best model only by an additional single variable (Table 3), suggesting the inclusion of uninformative variables. However, the maximized log likelihood of the second and third best model was 1.0 and 0.5 less, respectively, than the maximized log likelihood of the best model, so we judged the importance of these models based on their biological merits.
Fig. 4. Reproductive success of Common Loons (Gavia immer) across southern Canada as a function of longitude and year between 1992 and 2010, with projections into the future. Shown are model-averaged predictions from the best model from the first part of the analysis (Table 1), with longitude held at two selected values and lake area held at its median value. Means are shown across each of several arbitrary bin classes (dots) for two different sets of provinces to illustrate model fit, but be aware that these means were not the data used to fit the model. The horizontal dashed line is the minimum estimated number of six-week-old young per pair per year $(0.48)$ required to offset adult and juvenile mortality (Evers 2007).

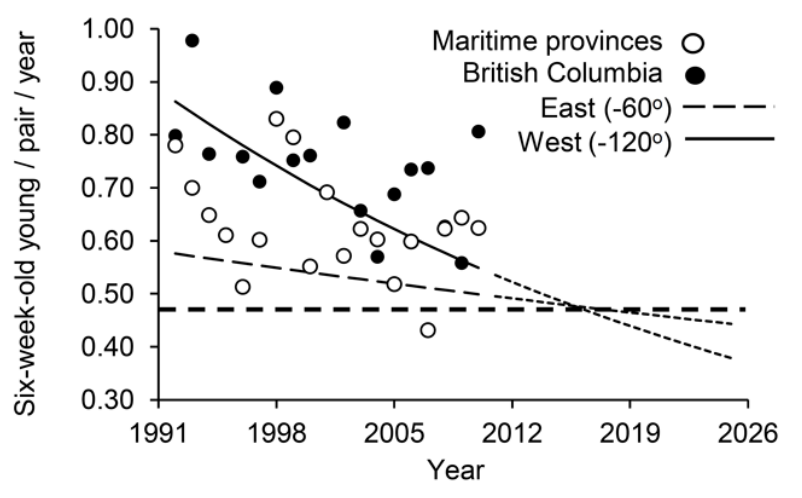

The best model predicted reproductive success with a mean and median absolute error of 0.6 and 0.5 six-week-old young per pair per year, respectively, and predicted reproductive success in 2011 with a mean and median absolute error of 0.7 and 0.5 six-week-old young per pair per year, respectively.

All four of the explanatory variables and all three of the interactions appeared in the supported models. Confidence limits around the model-averaged parameter estimate for $\mathrm{pH}$ did not overlap zero (Table 2). Confidence limits around 
Table 3. Model selection results for 25 candidate models explaining patterns in Common Loon (Gavia immer) reproductive success as a function of longitude, year, lake area, and $\mathrm{pH}$ across southern Canada between 1992 and 2010 . K = number of parameters; QAICc = quasiliklihood Akaike's information criterion; $\mathrm{w}=$ Akaike weight; LLA = log lake area. Parameter estimates with $95 \%$ confidence limits (lower, upper) are shown below for the best model; model-averaged estimates are given in Table 2.

\begin{tabular}{|c|c|c|c|c|}
\hline Model & $K$ & $Q A I C c$ & $\Delta \mathrm{QAICc}$ & $w$ \\
\hline Year + LLA + pH & 5 & 6610.2 & 0.0 & 0.30 \\
\hline Year + LLA + pH + Year*pH & 6 & 6610.5 & 0.4 & 0.25 \\
\hline Year + LLA + pH + LLA*pH & 6 & 6611.4 & 1.2 & 0.16 \\
\hline Year $+\mathrm{pH}$ & 4 & 6612.8 & 2.6 & 0.08 \\
\hline Year $+\mathrm{pH}+$ Year*pH & 5 & 6613.1 & 2.9 & 0.07 \\
\hline Longitude + Year $+\mathrm{pH}+$ Longitude $*$ Year & 6 & 6613.3 & 3.2 & 0.06 \\
\hline Longitude + Year $+\mathrm{pH}$ & 5 & 6614.0 & 3.9 & 0.04 \\
\hline Longitude + Year $+\mathrm{pH}+$ Year*pH & 6 & 6614.3 & 4.2 & 0.04 \\
\hline $\mathrm{LLA}+\mathrm{pH}$ & 4 & 6623.5 & 13.4 & 0.00 \\
\hline Longitude $+\mathrm{LLA}+\mathrm{pH}$ & 5 & 6624.0 & 13.9 & 0.00 \\
\hline $\mathrm{LLA}+\mathrm{pH}+\mathrm{LLA}^{*} \mathrm{pH}$ & 5 & 6624.7 & 14.5 & 0.00 \\
\hline Longitude + LLA + pH + LLA*pH & 6 & 6625.1 & 14.9 & 0.00 \\
\hline $\mathrm{pH}$ & 3 & 6626.0 & 15.8 & 0.00 \\
\hline Longitude $+\mathrm{pH}$ & 4 & 6626.6 & 16.5 & 0.00 \\
\hline Year + LLA & 4 & 6649.2 & 39.1 & 0.00 \\
\hline Longitude + Year + LLA + Longitude* Year & 6 & 6649.7 & 39.6 & 0.00 \\
\hline Longitude + Year + LLA & 5 & 6650.5 & 40.3 & 0.00 \\
\hline Longitude + Year + LLA + pH + Longitude*Year + Year*pH + LLA*pH & 10 & 6659.3 & 49.1 & 0.00 \\
\hline LLA & 3 & 6660.4 & 50.2 & 0.00 \\
\hline Year & 3 & 6661.5 & 51.4 & 0.00 \\
\hline Longitude + Year + Longitude* Year & 5 & 6661.9 & 51.8 & 0.00 \\
\hline Longitude + Year & 4 & 6662.0 & 51.8 & 0.00 \\
\hline Longitude + LLA & 4 & 6662.1 & 51.9 & 0.00 \\
\hline Intercept-only & 2 & 6672.1 & 61.9 & 0.00 \\
\hline Longitude & 3 & 6673.2 & 63.0 & 0.00 \\
\hline
\end{tabular}

model-averaged parameter estimates for year and log lake area also did not overlap zero (not reported, note that parameter estimates and associated $95 \%$ confidence limits for longitude, year, and log lake area in Table 2 are based on the model set from the first part of the analysis). By contrast, the parameter estimate for longitude overlapped zero (not reported). However, the data in this part of the analysis were mostly (> $95 \%$ ) from Ontario and eastwards, i.e., east of $-100^{\circ}$ longitude, which provided a limited assessment of the effect of longitude, because as noted above, reproductive success is known to be higher in the west than in the east (Timmermans and Jones 2002). Thus, longitude likely was important, but its effects were captured only in the first part of the analysis, so we based all of our inferences regarding longitude on models from the first part of the analysis and ignored models that included longitude in this (second) part of the analysis.

The number of six-week-old young per pair per year increased by 0.43 as $\mathrm{pH}$ increased from 5 to 9 (Fig. 3). At any given $\mathrm{pH}$, breeders on 2500 ha lakes produced $\sim 0.1$ more six-week-old young per pair per year than breeders on 20 ha lakes, which suggested that the log lake area $\times \mathrm{pH}$ interaction was unimportant (Fig. 5). Model-predicted values suggested that reproductive success dropped below the source-sink threshold
Fig. 5. Reproductive success of Common Loons (Gavia immer) across southern Canada as a function of lake area and $\mathrm{pH}$ between 1992 and 2010. Shown are model-averaged predictions from the third best model from the second part of the analysis (Table 3), with log lake area held at two selected values and year held at its median value. Means are shown across each of several arbitrary bin classes (dots) for two different lake size categories to illustrate model fit, but be aware that these means were not the data used to fit the model. The horizontal dashed line is the minimum estimated number of six-week-old young per pair per year (0.48) required to offset adult and juvenile mortality (Evers 2007).

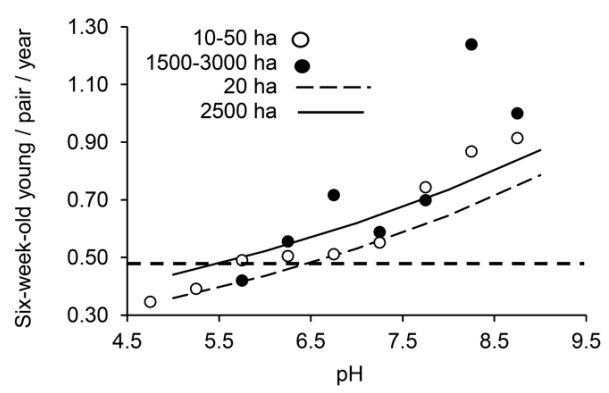


of 0.48 six-week-old young per pair per year (Evers 2007) on 20 ha lakes at $\mathrm{pH} 6.4$ (range: 5.8 - 7.1) and on 2500 ha lakes at pH 5.5 (4.1 - 6.6; Fig. 5). In any given year, breeders on $\mathrm{pH}$ 8.0 lakes produced $\sim 0.22$ more six-week-old young per pair per year than breeders on $\mathrm{pH} 6.0$ lakes, which suggested that the year $\times \mathrm{pH}$ interaction was unimportant (Fig. 6). Modelpredicted values suggested that the number of six-week-old young per pair per year may have dropped below the sourcesink threshold on pH 6.0 lakes as early as 2001 (1995-2009), whereas the number of six-week-old young per pair per year on $\mathrm{pH} 8.0$ lakes may not pass below the threshold until 2034 (2019-2062; Fig. 6).

Fig. 6. Reproductive success of Common Loons (Gavia immer) across southern Canada as a function of $\mathrm{pH}$ and year between 1992 and 2010, with projections into the future. Shown are model-averaged predictions from the second best model from the second part of the analysis (Table 3), with $\mathrm{pH}$ held at two selected values and log lake area held at its median value. Means are shown across each of several arbitrary bin classes (dots) for two different $\mathrm{pH}$ categories to illustrate model fit, but be aware that these means were not the data used to fit the model. The horizontal dashed line is the minimum estimated number of six-week-old young per pair per year $(0.48)$ required to offset adult and juvenile mortality (Evers 2007).

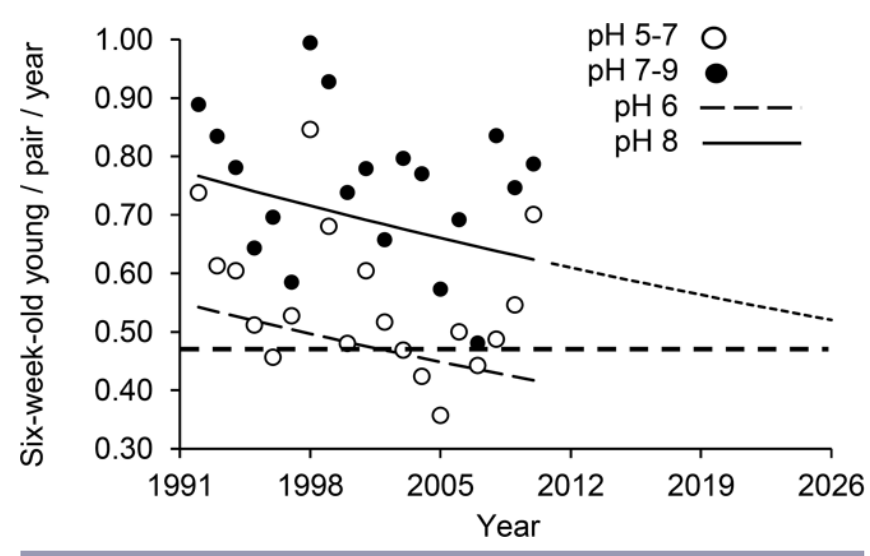

\section{DISCUSSION}

The number of Common Loon young per pair per year across southern Canada decreased from west-to-east, decreased between 1992 and 2010, increased as lake area increased, and increased as $\mathrm{pH}$ increased. The relationships were likely linked to acid- or temperature-mediated exposure to methylmercury and/or acid-induced reductions in forage fish. Methylmercury concentrations are higher (e.g., Evers et al. 1998) and pH is lower (e.g., Minns et al. 2008) in southeastern than in southwestern Canada, which likely explains why reproductive success in this study was lower in the southeast than in the southwest. Methylmercury is increasing over time in some lakes (e.g., Meyer et al. 2011) and pH is remaining stable over time in most lakes in southeastern Canada (Jefferies et al. $2003 a$ ), which likely explains why reproductive success in this study decreased over time. Methylmercury concentrations are higher (e.g., Bodaly et al. 1993) and pH (e.g., Eilers et al. 1983) and abundance of forage fish (e.g., Piper et al. 2012) are lower in smaller than in larger lakes, which likely explains why reproductive success in this study was lower in smaller than in larger lakes. Also, methylmercury concentrations are higher where $\mathrm{pH}$ is lower (e.g., Jeremiason et al. 2006), which combined with the direct negative effects of low $\mathrm{pH}$ on food supply, likely explains why reproductive success in this study was lower where $\mathrm{pH}$ was lower.

The geographically consistent link between low $\mathrm{pH}$, associated methylmercury exposure, and reduced Common Loon reproductive success in this study and others (e.g., Parker 1988, McNicol et al. 1995, Meyer et al. 1995, 1998, Merrill et al. 2005, Burgess and Meyer 2008, Alvo 2009, Piper et al. 2012) suggests that mercury and acid precipitation are among the most important drivers of Common Loon reproductive success in southern Canada, a conclusion also made by Evers et al. (2008) in the adjacent northeastern United States. Thus, the temporal decline in Common Loon reproductive success in this study, and in Ontario (1981 to 1999; McNicol et al. 1995, Weeber 1999, Jefferies et al. 2003a), suggests that aquatic ecosystem health is not improving in southern Canada despite commendable and successful efforts by the Canadian and United States governments and industry to reduce emissions of mercury and the harmful components of acid precipitation (USEPA 2006, Environment Canada 2011). Indeed, $\mathrm{pH}$ remained stable in most lakes, and increased in relatively few lakes, in Ontario, Quebec, Nova Scotia, and Newfoundland during the 1990s, perhaps requiring decades before $\mathrm{pH}$ increases in most lakes (e.g., Kemp 1999, Clair et al. 2002, Jefferies et al. 2003a,b). Similarly, methylmercury concentrations increased in fish and loons in widely scattered eastern locations between the mid-1990s and mid-2000s (Madsen and Stern 2007, Monson 2009, Rasmussen et al. 2007, Wyn et al. 2010).

Teasing apart the direct negative effects and interactions of mercury and acid precipitation on Common Loon reproductive success is challenging. Acid precipitation causes reductions in fish abundance (Howells et al. 1983), which reduces loon reproductive success (Alvo et al. 1988, Parker 1988, Merrill et al. 2005, Alvo 2009), even though on some lakes acid may improve loon foraging success by increasing water clarity or increasing numbers of small fish by eliminating predatory fish (Eriksson 1985, Burgess and Meyer 2008). Acid precipitation also increases methylmercury availability and associated mercury toxicity in adults and young (Evers et al. 2008), which reduces reproductive success (Barr 1986, Burgess and Meyer 2008). However, acid precipitation and associated lake acidity is not known, at least currently, to be increasing faster in 
southwestern than in southeastern Canada (Aherne and Shaw 2010). Therefore, our unexpected finding that reproductive success is declining more steeply in southwestern than in southeastern Canada suggests that factors unrelated to acid deposition are involved (e.g., Watras and Morrison 2008).

Even though methylmercury concentrations are lower in lake water, fish, and Common Loons in the west than in the east, concentrations may be increasing faster over time in the west than in the east. Increasing mercury deposition from increasing Asian emissions (Durnford et al. 2010, Pirrone et al. 2010) or increasing numbers and extent of wildfires (Bergeron and Flannigan 1995, Stocks et al. 1998), which release mercury stored in plant tissues (Sigler et al. 2003) and sediments (Turetsky et al. 2006) may be partly responsible. Western Canada is also heating up faster than eastern Canada (Zhang et al. 2011), which may be increasing methylmercury production more in the west than in the east by increasing microbial activity (Downs et al. 1998) or by favoring methylation over demethylation pathways (Shin and Krenkel 1976, Wright and Hamilton 1982, Ramlal et al. 1993). Thus, temperature-mediated increases in methylmercury, in addition to acid-induced negative effects, may be important drivers of the west-to-east patterns we identified in this study (e.g., Bodaly et al. 1993). This possibility warrants further research.

Other studies have also concluded that mechanisms, independent of concurrent declines in atmospheric deposition of mercury and acid precipitation, are capable of increasing methylmercury concentrations in lakes over time. For example, drought exposes sediments, which allows for oxidation of inert sulfur that is subsequently flushed by runoff into lakes where it fuels methylmercury production by sulfurreducing bacteria (e.g., Watras and Morrison 2008, Meyer et al. 2011). Nonetheless, acid-induced increases in methylmercury may become problematic in southwestern Canada in the future because acid precipitation emissions in the region may increase over time with increasing industrial activity (Aherne and Shaw 2010).

Our results suggest a declining trend in the number of sixweek-old young per pair per year between 1992 and 2010 for breeding Common Loons across southern Canada (Fig. 3). By contrast, the breeding bird survey (BBS) shows a steady increase in numbers of $1.2 \%$ per year (Sauer et al. 2011), and expert opinion suggests stable or increasing numbers (Evers 2007) for the Common Loon in southern Canada during the same time period. However, our estimates of reproductive success suggest that productivity across southern Canada is currently still above the demographic source-sink threshold, i.e., six-week-old young per pair per year are currently $>0.48$ (Evers 2007). Thus, declines in numbers of breeders are not expected until sometime in the future, assuming that there is no adjacent source to offset the losses, e.g., breeders in northern Canada. In addition, declining numbers of breeders are expected to lag behind declining numbers of young because of replenishment from large numbers of nonbreeding young adults (Grear et al. 2008), which take 4 to 11 years to secure breeding territories (Evers 2007). The lag could be even longer because of large numbers of young produced about every 10 years (about 1.5 times the long-term mean) under what must be exceptionally good but poorly understood conditions (Evers 2007). Indeed, large annual variation in reproductive success is readily evident by looking at any figure with year on the horizontal axis in this study, and should be duly noted as contributing a great deal of uncertainty to our projections of when reproductive success may drop below the demographic source-sink threshold.

Our results also indicate that Common Loon reproductive success on pH 6.0 lakes in southern Canada may have dropped below the demographic source-sink threshold as early as 2001. By contrast, reproductive success on pH 8.0 lakes, which was $\sim 0.22$ six-week-old young per pair per year higher than on pH 6.0 lakes, may not drop below the threshold until 2034 (Fig. 6). It may be that a surplus of offspring is being produced on higher-pH lakes, which is driving upward temporal trends in the number of breeders (Sauer et al. 2011). However, given that reproductive success is also declining over time on higher-pH lakes (Fig. 6) suggests that the surplus will become depleted at some point in the future, after which the number of breeders will start to decline. This result may illustrate, at least in part, why breeding Common Loons prefer to settle on higher $\mathrm{pH}$ rather than lower $\mathrm{pH}$ lakes (e.g., McNicol et al. 1995, Alvo 2009). Also, according to our results, a pair can raise $\sim 0.1$ more young per year at a given $\mathrm{pH}$ on a 2500 ha lake compared to a 20 ha lake (Fig. 5). This result may partially explain why breeding Common Loons prefer to settle on larger compared to smaller lakes (e.g., Kuhn et al. 2011) because larger lakes often have higher $\mathrm{pHs}$ and more food than smaller lakes (e.g., Rago and Wiener 1986, Matuszek and Beggs 1988, McNicol et al. 1995).

Our study was correlative, and because correlation does not mean causation, there may be confounding factors that explain the patterns we identified. Lead ingested by loons causes neurological symptoms similar to mercury and anthropogenic airborne lead emissions and deposition patterns are similar to that of acid precipitation (Carignan et al. 2002), which could cause broad-scale reductions in reproductive success (Pokras and Chafel 1992, Franson et al. 2003). However, lead concentrations in the tissues of breeding Common Loons in Atlantic Canada, where reproductive success was lowest in this study, are well below the threshold for reproductive impairments (Burgess et al. 2005). Some studies have found that Common Loon reproductive success is negatively affected by shoreline development (Heimberger et al. 1983) and human activity (Ream 1976, Strong and Bissonette 1989). However, not all pairs are equally affected (Caron and Robinson 1994, McCarthy and Destefano 2011) and broad- 
scale citizen science programs in Minnesota and New York (McIntyre 1988) and Nova Scotia and Ontario (Weeber 1999, Badzinski and Timmermans 2006) found no effect of shoreline development or human activity on reproductive success. Plus, human disturbance measures did not affect Common Loon reproductive success beyond the effects of annual variation, lake area, and $\mathrm{pH}$ according to CLLS data in Ontario between 1981 and 1997 (Weeber 1999). Type E botulism, emaciation syndrome, and oil spills could also negatively affect adult body condition and, in turn, reproductive success, but the negative effects of these factors are likely more localized than the apparently mercury-, acid precipitation-, and temperaturerelated patterns we observed. Last, it is possible that the temporal decline in reproductive success was attributable to senescence of long-lived individuals monitored over time. However, only a very small proportion of lakes in this study were monitored for several years (Fig. 2), such that the sample of lakes changed between years. Thus, any effect from monitoring the same individuals over time was minimal.

CLLS participants chose their own survey lakes, which may be larger, on average, than all of the lakes used by breeding Common Loons in southern Canada. For instance, a stratified random sample from all lakes $(N=81,494)$ within a 193,000 $\mathrm{km}^{2}$ area in Manitoba and Saskatchewan suggests that $70 \%$ of lakes that are suitable for breeding Common Loons, i.e., > 10 ha in area, are less than 50 ha (Jefferies et al. 2010). By contrast, only $20 \%$ of the lakes sampled in approximately the same $193,000 \mathrm{~km}^{2}$ area in this study ( $n=101$ lakes) were less than 50 ha. In this study reproductive success was lower on smaller lakes and lakes with lower $\mathrm{pH}$, so some of our estimates of reproductive success may be biased high because of underrepresentation of smaller lakes, which also tend to have lower $\mathrm{pH}$. It is unknown by how much we may have overestimated reproductive success because the distribution of lake sizes and lake pHs used by breeding Common Loons in southern Canada is poorly understood. Thus, actual reproductive success, and by extension lake health, may have been lower than some of the estimates reported in this study.

Various suboptimal $\mathrm{pH}$ thresholds have been estimated for aquatic wildlife. Damage to zooplankton, macroinvertebrates, fish, and loons occurs below pH 5.5 - 6.0 according to data from over 2000 lakes across southeastern Canada (Doka et al. 2003). Another estimate suggests that damage occurs below pH 6.0 for fish and other aquatic biota (Morrison 2004). The number of Common Loon young per pair per year declines below pH 6.0 based on 25 years of data across 38 lakes near Sudbury, Ontario (Alvo 2009). In this study, the number of six-week-old young per pair per year fell below the sourcesink threshold ( 0.48 six-week-old young per pair per year; Evers 2007) on 20 ha lakes at pH 6.4 and on 2500 ha lakes and at $\mathrm{pH}$ 5.5. This range ( $\mathrm{pH} 5.5-6.4)$ is very similar to the range found in the studies cited above ( $\mathrm{pH} 5.5$ - 6.0). However, our upper estimate is slightly higher ( $\mathrm{pH} 6.4$ vs. $\mathrm{pH} 6.0$ ), suggesting that more lakes may be at risk because of acid damage than previously thought. Although how many more are at risk is unclear, because as noted above, the distribution of lake sizes used by breeding Common Loons in southern Canada is poorly understood.

We used data on the reproductive success of Common Loons collected by a large network of citizen scientists to indirectly describe patterns in the health of southern Canadian lakes with respect to mercury and acid precipitation. Gathering such large amounts of data without a program such as Bird Studies Canada's CLLS would not have been possible, which highlights the utility of using citizen science programs to monitor wildlife as indicators of environmental stress. The results support further action to abate emissions of mercury and the harmful components of acid precipitation throughout North America and globally (Morrison et al. 2004, Smith and Trip 2005, Cain et al. 2011).

Responses to this article can be read online at: http://www.ace-eco.org/issues/responses.php/569

\section{Acknowledgments:}

We are grateful for the dedication of thousands of CLLS participants, whose collective effort made the study possible. We are also grateful for the coordination and promotion of the CLLS by Kathy Jones and a large team of regional ambassadors across southern Canada. Anna Calvert, Karla Falk, Jon McCracken, Kristyn Richardson, Phil Taylor, Ron Tozer, and two anonymous reviewers provided helpful comments that improved the paper. Ken Minns kindly provided the raw data summarized in Minns et al. (2008), which greatly increased our sample size for $\mathrm{pH}$. Bird Studies Canada is thankful for the continuing support of the CLLS by the TD Friends of the Environment Foundation, Kenneth M. Molson Foundation, and participant membership fees; and the past support by Biodiversity Institute, Environment Canada, Environmental Partners Fund, James L. Ballie Memorial Fund, North American Loon Fund, Northern Reflections, Ontario Federation of Anglers and Hunters, Ontario Wildlife Foundation, Shell Environmental Fund, The Millennium Fund, The Peacock Foundation, The Ontario Trillium Foundation, The Wildlife Toxicology Fund, and Volkswagon.

\section{LITERATURE CITED}

Aherne, J., R. G. Semkin, J. J. Gibson, and I. Wong. 2010. Recently surveyed lakes in northern Manitoba and Saskatchewan, Canada: characteristics and critical loads of acidity. Journal of Limnology 69 Supplement 1:45-55.

Aherne, J., and D. P. Shaw. 2010. Impacts of sulphur and nitrogen deposition in western Canada. Journal of Limnology 
69 Supplement 1:1-3. http://dx.doi.org/10.4081/jlimnol.2010. $\underline{\mathrm{s} 1.1}$

Alvo, R. 2009. Common Loon, Gavia immer, breeding success in relation to lake $\mathrm{pH}$ and lake size over 25 years. Canadian Field-Naturalist 123:146-156.

Alvo, R., D. J. T. Hussell, and M. Berrill. 1988. The breeding success of Common Loons (Gavia immer) in relation to alkalinity and other lake characteristics in Ontario. Canadian Journal of Zoology 66:746-752.

Arnold, T. W. 2010. Uninformative parameters and model selection using Akaike's information criterion. Journal of Wildlife Management 74:1175-1178.

Badzinski, S. S., and S. T. A. Timmermans. 2006. Factors influencing productivity of Common Loons (Gavia immer) breeding on circumneutral lakes in Nova Scotia, Canada. Hydrobiologia 567:215-226. http://dx.doi.org/10.1007/ s10750-006-0043-1

Barr, J. F. 1986. Population dynamics of the Common Loon (Gavia immer) associated with mercury-contaminated waters in north-western Ontario. Canadian Wildlife Service Occasional Paper 56.

Bates, D., M. Maechler, and B. Bolker. 2012. lme4: linear mixed-effects models using S4 classes. Version 0.999375-42. R Foundation for Statistical Computing, Vienna, Austria. [online] URL: http://CRAN.R-project.org/package=lme4

Bergeron, Y., and M. D. Flannigan. 1995. Predicting the effects of climate change on fire frequency in the southeastern Canadian boreal forest. Water, Air, and Soil Pollution 82:437-444. http://dx.doi.org/10.1007/BF01182853

Bird Studies Canada. 2011. Canadian Lakes Loon Survey. Bird Studies Canada, Port Rowan, Ontario, Canada. [online] URL: http://www.bsc-eoc.org/volunteer/clls/

Bodaly, R. A., J. W. M. Rudd, R. J. P. Fudge, and C. A. Kelly. 1993. Mercury concentrations in fish related to size of remote Canadian Shield lakes. Canadian Journal of Fisheries and Aquatic Sciences 50:980-987. http://dx.doi.org/10.1139/ $\underline{\text { f93-113 }}$

Brown, D. J. A. 1982. The effect of $\mathrm{pH}$ and calcium on fish and fisheries. Water, Air, and Soil Pollution 18:343-351. http:// dx.doi.org/10.1007/BF02419422

Burgess, N. M., D. C. Evers, and J. D. Kaplan. 2005. Mercury and other contaminants in Common Loons breeding in Atlantic Canada. Ecotoxicology 14:241-252. http://dx.doi. org/10.1007/s10646-004-6271-0

Burgess, N. M., and M. W. Meyer. 2008. Methylmercury exposure associated with reduced productivity in Common Loons. Ecotoxicology 17:83-91. http://dx.doi.org/10.1007/ s10646-007-0167-8
Burnham, K. P., and D. R. Anderson. 2002. Model selection and multimodel inference: a practical information-theoretic approach. Springer-Verlag, New York, New York, USA.

Burnham, K. P., D. R. Anderson, and K. P. Huyvaert. 2011. AIC model selection and multimodel inference in behavioral ecology: some background, observations, and comparisons. Behavioral Ecology and Sociobiology 65:23-35. http://dx.doi. org/10.1007/s00265-010-1029-6

Cain, A., J. Taylor Morgan, and N. Brooks. 2011. Mercury policy in the Great Lakes states: past success and future opportunities. Ecotoxicology 20:1500-1511. http://dx.doi. org/10.1007/s10646-011-0764-4

Carignan, J., A. Simonetti, and C. Gariépy. 2002. Dispersal of atmospheric lead in northeastern North America as recorded by epiphytic lichens. Atmospheric Environment 36:3759-3766. http://dx.doi.org/10.1016/S1352-2310(02)00294-7

Caron Jr., J. A., and W. L. Robinson. 1994. Response of breeding Common Loons to human activity in upper Michigan. Hydrobiologia 279/280:431-438. http://dx.doi. org/10.1007/BF00027874

Celo, V., D. R. S. Lean, and S. L. Scott. 2006. Abiotic methylation of mercury in the aquatic environment. Science of the Total Environment 368:126-137. http://dx.doi. org/10.1016/j.scitotenv.2005.09.043

Champoux, L., D. C. Masse, D. Evers, O. P. Lane, M. Plante, and S. T. A. Timmermans. 2006. Assessment of mercury exposure and potential effects on Common Loons (Gavia immer) in Quebec. Hydrobiologia 567:263-274. http://dx.doi. org/10.1007/s10750-006-0066-7

Clair, T. A., J. M. Ehrman, A. J. Ouellett, G. Brun, D. Lockerbie, and C.-U. Ro. 2002. Changes in freshwater acidification trends in Canada's Atlantic provinces, 1983-1997. Water, Air, and Soil Pollution 135:335-354. http:// dx.doi.org/10.1023/A:1014785628141

Doka, S. E., D. K. McNicol, M. L. Mallory, I. Wong, C. K. Minns, and N. D. Yan. 2003. Assessing potential for recovery of biotic richness and indicator species due to changes in acidic deposition and lake $\mathrm{pH}$ in five areas of southeastern Canada. Environmental Monitoring and Assessment 88:53-101. http:// dx.doi.org/10.1023/A:1025548518991

Downs, S. G., C. L. MacLeod, and J. N. Nester. 1998. Mercury in precipitation and its relation to bioaccumulation in fish: a literature review. Water, Air, and Soil Pollution 108:149-187. http://dx.doi.org/10.1023/A:1005023916816

Driscoll, C. T., Y.-J. Han, C. Y. Chen, D. C. Evers, K. Fallon Lambert, T. M. Holsen, N. C. Kamman, and R. K. Munson. 2007. Mercury contamination in forest and freshwater ecosystems in the northeastern United States. Bioscience 57:17-28. http://dx.doi.org/10.1641/B570106 
Driscoll, C. T., G. B. Lawrence, A. J. Bulger, T. J. Butler, C. S. Cronan, C. Eagar, K. F. Lambert, G. E. Likens, J. L. Stoddard, and K. C. Weathers. 2001. Acid deposition in the northeastern United States: sources and inputs, ecosystem effects, and management strategies. Bioscience 51:180-198. http://dx.doi.org/10.1641/0006-3568(2001)051[0180:ADITNU] 2.0.CO;2

Durnford, D., A. Dastoor, D. Figueras-Nieto, and A. Ryjkov. 2010. Long range transport of mercury to the arctic and across Canada. Atmospheric Chemistry and Physics 10:6063-6086. http://dx.doi.org/10.5194/acp-10-6063-2010

Eckley, C. S., and H. Hintelmann. 2006. Determination of mercury methylation potentials in the water column of lakes across Canada. Science of the Total Environment 368:111-125. http://dx.doi.org/10.1016/j.scitotenv.2005.09.042

Eilers, J. M., G. E. Glass, K. E. Webster, and J. A. Rogalla. 1983. Hydrologic control of lake susceptibility to acidification. Canadian Journal of Fisheries and Aquatic Sciences 40:1896-1904. http://dx.doi.org/10.1139/f83-220

Environment Canada, 2011. National pollutant release inventory. Environment Canada, Gatineau, Quebec, Canada. [online] URL: http://www.ec.gc.ca/inrp-npri/default.asp? lang=En\&n=4A577BB9-1.

Eriksson, M. O. G. 1985. Prey detectability for fish-eating birds in relation to fish density and water transparency. Ornis Scandinavica 16:1-7. http://dx.doi.org/10.2307/3676567

Evers, D. 2006. Loons as indicators of aquatic integrity. Environmental Bioindicators 1:18-21.

Evers, D. C., 2007. Status assessment and conservation plan for the Common Loon (Gavia immer) in North America. BRI Report 2007-20. U.S. Fish and Wildlife Service, Hadley, Massachusetts, USA.

Evers, D. C., J. D. Kaplan, M. W. Meyer, P. S. Reaman, W. E. Braselton, A. Major, N. Burgess, and A. M. Scheuhammer. 1998. Geographic trend in mercury measured in Common Loon feathers and blood. Environmental Toxicology and Chemistry 17:173-183. http://dx.doi.org/10.1002/etc.5620170206

Evers, D. C., J. D. Paruk, J. W. Mcintyre, and J. F. Barr. 2010. Common Loon (Gavia immer). In A. Poole and F. Gill, editors. The birds of North America, No. 313. The Birds of North America, Philadelphia, Pennsylvania, USA.

Evers, D. C., L. J. Savoy, C. R. DeSorbo, D. E. Yates, W. Hanson, K. M. Taylor, L. S. Siegel, J. H. Cooley Jr., M. S. Bank, A. Major, K. Munney, B. F. Mower, H. S. Vogel, N. Schoch, M. Pokras, M. W. Goodale, and J. Fair. 2008. Adverse effects from environmental mercury loads on breeding Common Loons. Ecotoxicology 17:69-81. http://dx.doi. org/10.1007/s10646-007-0168-7
Flom, P. L., and S. M. Strauss. 2003. Some graphical methods for interpreting interactions in logistic and OSL regression. Multiple Linear Regression Viewpoints 29(1).

Franson, J. C., S. P. Hansen, T. E. Creekmore, C. J. Brand, D. C. Evers, A. E. Duerr, and S. DeStefano. 2003. Lead fishing weights and other fishing tackle in selected waterbirds. Waterbirds 26:345-352. http://dx.doi.org/10.1675/1524-4695 (2003)026[0345:LFWAOF]2.0.CO;2

Grear, J. S., M. W. Meyer, J. H. Cooley Jr., A. Kuhn, W. H. Piper, M. G. Mitro, H. S. Vogel, K. M. Taylor, K. P. Kenow, S. M. Craig, and D. E. Nacci. 2008. Population growth and demography of Common Loons in the northern United States. Journal of Wildlife Management 73:1108-1115. http://dx.doi. org/10.2193/2008-093

Grigal, D. F. 2002. Inputs and outputs of mercury from terrestrial watersheds: a review. Environmental Reviews 10:1-39. http://dx.doi.org/10.1139/a01-013

Grigal, D. F. 2003. Mercury sequestration in forests and peatlands: a review. Journal of Environmental Quality 32:393-405.

Heimberger, M., D. Euler, and J. Barr. 1983. The impact of cottage development on Common Loon reproductive success in central Ontario. Wilson Bulletin 95:431-439.

Howells, G. D., D. J. A. Brown, and K. Sadler. 1983. Effects of acidity, calcium, and aluminum on fish survival and productivity-a review. Journal of the Science of Food and Agriculture 34:559-570. http://dx.doi.org/10.1002/jsfa.2740340606

Jefferies, D. S., T. G. Brydges, P. J. Dillon, and W. Keller. $2003 b$. Monitoring the results of Canada/U.S.A. acid rain control programs: some lake responses. Environmental Monitoring and Assessment 88:3-19. http://dx.doi.org/10.1023/ A:1025563400336

Jefferies, D. S., T. A. Clair, S. Couture, P. J. Dillon, J. Dupont, W. B. Keller, D. K. McNicol, M. A. Turner, R. Vet, and R. Weeber. 2003a. Assessing the recovery of lakes in southeastern Canada from the effects of acid deposition. Ambio 32:176-182.

Jefferies, D. S., R. G. Semkin, J. J. Gibson, and I. Wong. 2010. Recently surveyed lakes in northern Manitoba and Saskatchewan, Canada: characteristics and critical loads of acidity. Journal of Limnology 69 Supplement 1:45-55.

Jeremiason, J. D., D. R. Engstrom, E. B. Swain, E. A. Nater, B. M. Johnson, J. E. Almendinger, B. A. Monson, and R. K. Kolka. 2006. Sulfate addition increases methyl mercury production in an experimental wetland. Environmental Science \& Technology 40:3800-3806. http://dx.doi. org/10.1021/es0524144

Jewett, S. C., and L. K. Duffy. 2007. Mercury in fishes of Alaska, with emphasis on subsistence species. Science of the 
Total Environment 387:3-27. http://dx.doi.org/10.1016/j. scitotenv.2007.07.034

Kamman, N. C., N. M. Burgess, C. T. Driscoll, H. A. Simonin, W. Goodale, J. Linehan, R. Estabrook, M. Hutcheson, A. Major, A. M. Scheuhammer, and D. A. Scruton. 2005. Mercury in freshwater fish of northeast North America - a geographic perspective based on fish tissue monitoring databases. Ecotoxicology 14:163-180. http://dx.doi.org/10.1007/ s10646-004-6267-9

Kellerhalls, M., S. Beauchamp, W. Belzer, P. Blanchard, F. Froude, B. Harvey, K. McDonald, M. Pilote, L. Piossant, K. Puckett, B. Schroeder, A. Steffen, and R. Tordon. 2003. Temporal and spatial variability of total gaseous mercury in Canada: results from the Canadian atmospheric mercury measurement network (CAMNet). Atmospheric Environment 37:1003-1011. http://dx.doi.org/10.1016/S1352-2310(02)00917-2

Kemp, A. 1999. Trends in lake water quality in southern Quebec following reductions in sulphur emissions. Scientific and Technical Report ST-212E. Environment Canada, Quebec Region, Montreal, Quebec, Canada.

Kenow, K. P., K. A. Grasman, R. K. Hines, M. W. Meyer, A. Gendron-Fitzpatrick, M. G. Spalding, and B. R. Gray. 2007. Effects of methylmercury exposure on the immune function of juvenile Common Loons (Gavia immer). Environmental Toxicology and Chemistry 26:1460-1469. http://dx.doi. org/10.1897/06-442R.1

Kenow, K. P., R. K. Hines, M. W. Meyer, S. A. Suarez, and B. R. Gray. 2010. Effects of methylmercury exposure on the behavior of captive-reared Common Loon (Gavia immer) chicks. Ecotoxicology 19:933-944. http://dx.doi.org/10.1007/ s10646-010-0475-2

Kuhn, A., J. Copeland, J. Cooley, H. Vogel, K. Taylor, D. Nacci, and P. August. 2011. Modeling habitat associations for the Common Loon (Gavia immer) at multiple scales in northeastern North America. Avian Conservation and Ecology 6(1): 4. http://dx.doi.org/10.5751/ACE-00451-060104

Lockhart, W. L., P. Wilkinson, B. N. Billeck, R. A. Danell, R. V. Hunt, G. J. Brunskill, J. Delaronde, and V. St. Louis. 1998. Fluxes of mercury to lake sediments in central and northern Canada inferred from dated sediment cores. Biogeochemistry 40:163-173. http://dx.doi.org/10.1023/ A:1005923123637

Madsen, E. R., and H. S. Stern. 2007. Time trends of methylmercury in walleye in northern Wisconsin: a hierarchical Bayesian analysis. Environmental Science \& Technology 41:4568-4573. http://dx.doi.org/10.1021/es0700294

Matuszek, J. E., and G. L. Beggs. 1988. Fish species richness in relation to lake area, $\mathrm{pH}$, and other abiotic factors in Ontario lakes. Canadian Journal of Fisheries and Aquatic Sciences 45:1931-1941. http://dx.doi.org/10.1139/f88-225

Mazerolle, M. J. 2013. AICcmodavg: model selection and multimodel inference based on $(Q) A I C(c)$. Version 1.20. $\mathrm{R}$ Foundation for Statistical Computing, Vienna, Austria. [online] URL: http://CRAN.R-project.org/package=AICcmodavg

McCarthy, K. P., and S. Destefano. 2011. Effects of spatial disturbance on Common Loon nest site selection and territory success. Journal of Wildlife Management 75:289-296. http:// dx.doi.org/10.1002/jwmg.50

McIntyre, J. W. 1988. The Common Loon: spirit of the northern lakes. University of Minnesota Press, Minneapolis, Minnesota, USA.

McIntyre, J. W., 1994. Loons in freshwater lakes. Hydrobiologia 279/280:393-413. http://dx.doi.org/10.1007/ BF00027871

McNicol, D. K., M. L. Mallory, and H. S. Vogel. 1995. Using volunteers to monitor the effects of acid precipitation on Common Loon (Gavia immer) reproduction in Canada: the Canadian lakes loon survey. Water, Air, and Soil Pollution 85:463-468. http://dx.doi.org/10.1007/BF00476872

Merrill, E. H., J. J. Hartigan, and M. W. Meyer. 2005. Does prey biomass or mercury exposure affect loon chick survival in Wisconsin? Journal of Wildlife Management 69:57-67. http://dx.doi.org/10.2193/0022-541X(2005)069<0057:DPBOME $>2.0$. $\mathrm{CO} ; 2$

Meyer, M. W., D. C. Evers, T. Daulton, and W. E. Braselton. 1995. Common Loons (Gavia immer) nesting on low pH lakes in northern Wisconsin have elevated blood mercury content. Water, Air, and Soil Pollution 80:871-880. http://dx.doi. org/10.1007/BF01189737

Meyer, M. W., D. C. Evers, J. J. Hartigan, and P. S. Rasmussen. 1998. Patterns of Common Loon (Gavia immer) mercury exposure, reproduction, and survival in Wisconsin, USA. Environmental Toxicology and Chemistry 17:184-190.

Meyer, M. W., P. W. Rasmussen, C. J. Watras, B. M. Fevold, and K. P. Kenow. 2011. Bi-phasic trends in mercury concentrations in blood of Wisconsin Common Loons during 1992-2010. Ecotoxicology 20:1659-1668. http://dx.doi. org/10.1007/s10646-011-0759-1

Minns, C. K., J. E. Moore, B. J. Shuter, and N. E. Mandrak. 2008. A preliminary national analysis of some key characteristics of Canadian lakes. Canadian Journal of Fisheries and Aquatic Sciences 65:1763-1778. http://dx.doi. org/10.1139/F08-110

Monson, B. A. 2009. Trend reversal of mercury concentrations in piscivorous fish from Minnesota lakes: 1982-2006. 
Environmental Science \& Technology 43:1750-1755. http:// dx.doi.org/10.1021/es8027378

Morrison, H. A., editor. 2004. 2004 Canadian acid deposition science assessment: summary of key results. Environment Canada, Gatineau, Quebec, Canada.

Nocera, J. J., and P. D. Taylor. 1998. In situ behavioral response of Common Loons associated with elevated mercury (Hg) exposure. Conservation Ecology 2(2): 10. [online] URL: http://www.ecologyandsociety.org/vol2/iss2/art10/

Parker, K. E. 1988. Common Loon reproduction and chick feeding on acidified lakes in the Adirondack Park, New York. Canadian Journal of Zoology 66:804-810. http://dx.doi. org/10.1139/z88-119

Perry, E., S. A. Norton, N. C. Kamman, P. M. Lorey, and C. T. Driscoll. 2005. Deconstruction of historic mercury accumulation in lake sediments, northeastern United States. Ecotoxicology 14:85-99. http://dx.doi.org/10.1007/s10646-004-6261-2

Piper, W. H., J. S. Grear, and M. W. Meyer. 2012. Juvenile survival in Common Loons Gavia immer: effects of natal lake size and pH. Journal of Avian Biology 43:280-288. http://dx. doi.org/10.1111/j.1600-048X.2012.05633.X

Pirrone, N., S. Cinnirella, X. Feng, R. B. Finkleman, H. R. Friedli, J. Leaner, R. Mason, A. B. Mukherjee, G. B. Stracher, D. G. Streets, and K. Telmer. 2010. Global mercury emissions to the atmosphere from anthropogenic and natural sources. Atmospheric Chemistry and Physics 10:5951-5964. http://dx. doi.org/10.5194/acp-10-5951-2010

Pokras, M. A., and R. Chafel. 1992. Lead toxicosis from lead fishing sinkers in adult Common Loons (Gavia immer) in New England. Journal of Zoo and Wildlife Medicine 23:92-97.

$\mathrm{R}$ Development Core Team. 2011. R: A language and environment for statistical computing. R Foundation for Statistical Computing, Vienna, Austria. ISBN 3-900051-07-0. [online] URL: http://www.R-project.org/

Rago, P. J., and J. G. Wiener. 1986. Does pH affect fish species richness when lake area is considered? Transactions of the American Fisheries Society 115:438-447. http://dx.doi. org/10.1577/1548-8659(1986)115<438:DPAFSR>2.0.CO;2

Ramlal, P. S., C. A. Kelly, J. W. M. Rudd, and A. Furutani. 1993. Sites of methyl mercury production in remote Canadian Shield. Canadian Journal of Fisheries and Aquatic Sciences 50:972-979. http://dx.doi.org/10.1139/f93-112

Rasmussen, P. W., C. S. Schrank, and P. A. Campfield. 2007. Temporal trends of mercury concentrations in Wisconsin walleye (Sander vitreus), 1982-2005. Ecotoxicology 16:541-550. http://dx.doi.org/10.1007/s10646-007-0160-2

Ream, C. H. 1976. Loon productivity, human disturbance, and pesticide residues in northern Minnesota. Wilson Bulletin $88: 427-432$.
Sauer, J. R., J. E. Hines, J. E. Fallon, K. L. Pardieck, D. J. Ziolkowski Jr., and W. A. Link. 2011. The North American breeding bird survey, Rresults and analysis 1966 - 2010. Version 12.07.2011. U.S. Geological Survey Patuxent Wildlife Research Center, Laurel, Maryland, USA. [online] URL: http://www.mbr-pwrc.usgs.gov/bbs/bbs.html

Scheuhammer, A. M., and P. J. Blancher. 1994. Potential risk to Common Loons (Gavia immer) from methylmercury exposure in acidified lakes. Hydrobiologia 279/280:445-455. http://dx.doi.org/10.1007/BF00027876

Scheuhammer, A. M., M. W. Meyer, M. B. Sandheinrich, and M. W. Murray. 2007. Effects of environmental methylmercury on the health of wild birds, mammals, and fish. AMBIO: A Journal of the Human Environment 36:12-19. http://dx.doi. org/10.1579/0044-7447(2007)36[12:EOEMOT]2.0.CO;2

Schindler, D. W., 1988. Effects of acid rain on freshwater ecosystems. Science 239:149-157. http://dx.doi.org/10.1126/ science.239.4836.149

Schroeder, W. H., and J. Munthe. 1998. Atmospheric mercury -an overview. Atmospheric Environment 32:809-822. http:// dx.doi.org/10.1016/S1352-2310(97)00293-8

Seewagen, C. L. 2010. Threats of environmental mercury to birds: knowledge gaps and priorities for future research. Bird Conservation International 20:112-123. http://dx.doi. org/10.1017/S095927090999030X

Shin, E.-B., and P. A. Krenkel. 1976. Mercury uptake by fish and biomethylation mechanisms. Journal (Water Pollution Control Federation) 48:473-501.

Sigler, J. M., X. Lee, and W. Munger. 2003. Emissions and long-range transport of gaseous mercury from a large-scale Canadian boreal forest fire. Environmental Science \& Technology 37:4343-4347. http://dx.doi.org/10.1021/es026401r

Smith, C. M., and L. J. Trip. 2005. Mercury policy and science in northeastern North America: the mercury action plan of the New England governors and eastern Canadian premiers. Ecotoxicology 14:19-35. http://dx.doi.org/10.1007/s10646-004-6257บ

Stocks, B. J., M. A. Fosberg, T. J. Lynham, L. Mearns, B. M. Wotton, Q. Yang, J.-Z. Jin, K. Lawrence, G. R. Hartley, J. A. Mason, and D. W. McKenney. 1998. Climate change and forest fire potential in Russian and Canadian boreal forests. Climate Change 38:1-13. http://dx.doi.org/10.1023/A:1005306001055

Strong, P. I. V. 1990. Suitability of the Common Loon as an indicator species. Wildlife Society Bulletin 18:257-261.

Strong, P. I. V., and J. A. Bissonette. 1989. Feeding and chickrearing areas of Common Loons. Journal of Wildlife Management 53:72-76. http://dx.doi.org/10.2307/3801308

Tabachnick, B. G., and L. S. Fidell. 1996. Using multivariate statistics. Third edition. California State University, Northridge, California, USA. 
Temme, C., P. Blanchard, A. Steffen, C. Banic, S. Beauchamp, L. Poissant, R. Tordon, and B. Wiens. 2007. Trend, seasonal and multivariate analysis study of total gaseous mercury data from the Canadian atmospheric mercury measurement network (CAMNet). Atmospheric Environment 41:5423-5441. http://dx.doi.org/10.1016/j.atmosenv.2007.02.021

Timmermans, S., and K. Jones. 2002. Western loons have higher productivity than eastern loons. Birdwatch Canada 20:18-19.

Turetsky, M. R., J. W. Harden, H. R. Friedli, M. Flannigan, N. Payne, J. Crock, and L. Radke. 2006. Wildfires threaten mercury stocks in northern soils. Geophysical Research Letters 33:L16403. http://dx.doi.org/10.1029/2005GL025595

U.S. Environmental Protection Agency (USEPA). 2006. EPA's roadmap for mercury. EPA-HQ-OPPT-2005-0013, USEPA, Washington, D.C., USA. [online] URL: http://www.epa.gov/ mercury/roadmap.htm.

Watras, C. J., and K. A. Morrison. 2008. The response of two remote, temperate lakes to changes in atmospheric mercury deposition, sulfate, and the water cycle. Canadian Journal of Fisheries and Aquatic Sciences 65:100-116. http://dx.doi. org/10.1139/f07-159

Weeber, R. C. 1999. Temporal patterns in breeding success of Common Loons in Ontario, 1981-1997. Final report, Bird Studies Canada to Environment Canada, Gatineau, Quebec, Canada. [online] URL: http://www.bsc-eoc.org/download/ cllstrndrpt.pdf

Willmott, C. J., and K. Matsuura. 2005. Advantages of the mean absolute error (MAE) over the root mean square error (RMSE) in assessing average model performance. Climate Research 30:79-82. http://dx.doi.org/10.3354/cr030079

Winfrey, M. R., and J. W. M. Rudd. 1990. Environmental factors affecting the formation of methylmercury in low $\mathrm{pH}$ lakes. Environmental Toxicology and Chemistry 9:853-869. http://dx.doi.org/10.1002/etc.5620090705

Wright, D. R., and R. D. Hamilton. 1982. Release of methyl mercury from sediments: effects of mercury concentration, low temperature, and nutrient addition. Canadian Journal of Fisheries and Aquatic Sciences 39:1459-1466. http://dx.doi. org/10.1139/f82-197

Wyn, B., K. A. Kidd, N. M. Burgess, R. A. Curry, and K. R. Munkittrick. 2010. Increasing mercury in yellow perch at a hotspot in Atlantic Canada: Kejimkujik National Park. Environmental Science \& Technology 44:9176-9181. http:// dx.doi.org/10.1021/es1018114

Xun, L., N. E. R. Campbell, and J. W. M. Rudd. 1987. Measurements of specific rates of net methyl mercury production in the water column and surface sediments of acidified and circumneutral lakes. Canadian Journal of
Fisheries and Aquatic Sciences 44:750-757. http://dx.doi. org/10.1139/f87-091

Zhang, X., R. Brown, L. Vincent, W. Skinner, Y. Feng, and E. Mekis. 2011. Canadian climate trends, 1950-2007. Canadian Biodiversity: Ecosystem Status and Trends 2010, Technical Thematic Report Series No. 5, Canadian Councils of Resource Ministers, Ottawa, Ontario, Canada. [online] URL: http://www.speciesatrisk.ca/resource/DOCUMENT/4876No.5 General\%20Climate\%20July\%202011 E.pdf

Zuur, A. F., E. N. Ieno, N. J. Walker, A. A. Saveliev, and G. M. Smith. 2009. Mixed effects models and extensions in ecology with R. Springer, New York, New York, USA. http:// dx.doi.org/10.1007/978-0-387-87458-6 